こぞつてこの使用を推奨しているものである。 ジーゼル燃料のセタン価の重要性は, エンジン設訢 にもある程度の影響をもつが, 大気の條件とエンジン の運転條件とによるもので, 始動時, 或は低荷重低運 転温度の場合特に重要性があり, 高荷重の場合，すな わちそれによつて生ずる運転温度の比較的高い場合は あまり重要性はないのである。
以上を要約与ると，わが国に抢いても米国の例之同 じ々，需要量の增加に伴いこれが対策としていわ的る 直溜溜分に対して分解溜分の割合が次第に堌加して助 く傾向に鑑みて，性状的に劣るこれらの燃料使用に対 する対策は, 石油会社, エンジン・メーカ両者の密接 な協力の下に，早急に確立しなければならない問題で あろう。

\title{
On the Diesel Fuels
}

\author{
by Takeshi Kamatani
}

(Nippon Oil Co., Ltd.)

SYNOPSIS :-Difference between diesel and gasoline engine, safety and economy of diesel fuel, significance of diesel engine to industry, traffic, and national defence, and the necessity for popularising use of diesels in those nations not having rich petroleum resources-such as German and Japan-was explained.

Next, classifications of diesel fuels by their use and viscosity, common nature of diesel fuels used in engines and special properties required before completion of the injection stage and after commencement of the combustion stage were refered to. A full explanation was given as to the relation between fuel injection and fuel viscosity.

Also, the characteristics of high viscosity fuel oil used in low-speed marine diesel engine and essential points in handling such viscous fuel were outlined.

Lastly, diesel fuels used in U.S.A. and that of our country was discussed.

U.D.C. 621.89

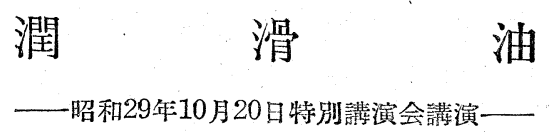

昭和石泊株式会社 品川研究所!若荣章

要旨 : 最近重要視され，かつ興味ある潤滑油関係について述べた。すなわち、タービン油につい ては添加刜を使用した油は極めて優秀な性能を示すとと，クエート原油からでも添加戍の使用によ

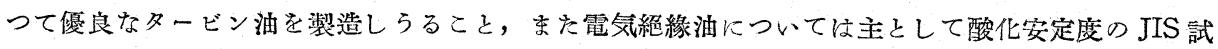
験に関連せる事項衫よび再生油の使用について述べ, 自動車用潤滑油についてங，特に Heavy Duty

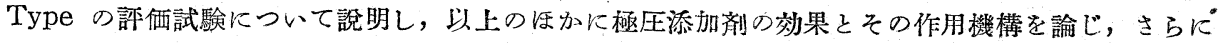
レッドゥッド粘度值の動粘度換算に関する新しい換算表について解說した。

\section{I 前 が き}

筆者は䝫年当燃料協会第 273 回例会で，最近における
潤滑油に関する諸問題について述べたが，既に一年以 上を経過している。本稿ではその後直面した関連事項 
を振返つてみたいと思う。JIS を審議する日本工業標 準調査会鬥渭泊尃門委員会は, 永井雄三郎委員長の下 に開催されているが，本会では特にタービン油や粘度 の分科会觉持っている。別に電文試験所電気絶縁材料 研觉会では絶縁油安定度試験法が検討されている。こ れらは明らかに使用面よりみた潤滑油の適正品質をい かに把握し，表現する心゙きかといった努力に結びつい ている。まずこれらを取上げ，ついで H.D. エンジン 油や境界潤滑などに触れてみたいと思う。大体の傾向 として，潤滑油の試験法はASTM をとのまま採択し ようとしているが，米国が石油の先進国で，乙かも現 在の日本に対して影響力の強いことから止むを得ない ことと思う。

\section{II タービン油}

昨年特タービン油に言及，酸化安定度試験には AS TM D 943，防錆試験には D 665 が広く用いられて いることを紹介乙, 適当な酸化防止郕と防錆剤を併用 するときは，1,000hr 後の酸価尼 1 以下に押えること ができると述へた。ところが本年 5 月高橋法男博士 は, タービン油の安定性についての見解を日立評論に 発表されている。内外多数のタービン油を試験する そ, 酸価 0.25 に達するまでの時間は, 直溜油で 40〜 $160 \mathrm{hr}$, 酸化防止剤の久在添加した単純抑制油で 1,150 〜 1,300hr，ささらに防錆郕の加わつた二重抑制油では $380 \sim 570 \mathrm{hr}$, さららに防鎘剂の酸化促進作用を押光るよ うな別の添加郕を併用した多重抑制油で 1,200〜 $2,500 \mathrm{hr}$ という成績を得, 世界的に定評ある外国製品 の安定度は，す心て $1,000 \mathrm{hr}$ の酸価が 0.4 までに大 るようだと述へている。中東原油のように，硫黄分の 多い原油から安定度の優れたタービン油をつくる困難 には深、理解劣示しているが, 米国 G. E. 会社で $1,000 \mathrm{hr}$ の酸価を 0.25 以下に押えていることと, こ のあたりから酸価き急増し，スラッジを析出し始める 傾向のあることを考慮して，この線を守りたいと述心 ている。

一ナタービン油は常に水または氷蒸気と接触しなが ら使われるので，金属面に錆を生じ易く，乙かも乳化 しやすい状態になる。高橋博士は抗孚化度についても 検討し，防錆剤の大らないタービン油で30前後，防鎘 剤の入つた泊では10前後に落着くであ万うといつてい る。油と水との界面張力の測定にも防錆剂の影響が認 められ，酸化防止剤のみの単純抑制油は 43〜53dyne/ cm であるが，防鋮珮の加わつた二重抑制油では 19〜 25dyne/cm であると関西電力の藤本氏は発表してい る。
米国に抢いても，抗孚化試験（ASTM D157〜 51T) は添加剤使用油には適用しないと前置きしている。 Federal 法としてハーシェル試験機を用いる抗孚化度 試験法が規定されているが，両者の関連は明らかにさ れていない。この抗乳化性は単に放置中でき，酸素ま たは水分を吸収するためか，相当低下する場合が認め られている。

さて昭和石油においても，クエイト原油から特ター ビン油を製造することに苦心しているが，硫黄分や芳 查族成分に充分留意して精製した基油と適当な添加凬 を使うと, $1,000 \mathrm{hr}$ で酸価 0.006 , 抗孚化度 $70,2000 \mathrm{hr}$ の酸価 0.06 程度のものを得ている。同じ基油でも防 錆媯が変わると, $1,000 \mathrm{hr}$ で酸価 0.32 , 抗乳化度 9 に 下が多場合もある。防鋅刜の優劣が酸化試験に大きな 影響を示すことは注目すべき事柄である。なお，米軍 規格 MIL-L-17331 および 17672 では, 1,000hr 後 の酸価を 2.0 以下に押えている。

Esso Petr. Co. の G. H. Clark はヌービン油の 保守管理について，界面張力が 18dyne/cm 以下に低 下したときは，スラッジ柝出の盧れがあるから注意す る必要があると述へ，沈搌物や水分が急増したなら ぱ，その原因を追究し，対策を講じるこ之を勧的てい る。前述のように関西電力では, かねてより使用中の タービン油の界面張力の変化に注意を払つている。

またタービン油などの賩油ヌンク内面，特に油面以 上に発錆する場合が多く，各種の耐油塗料の便用が紹 介されている。新油を初めて張込むとき，または使用 限度に達した油を交換するときには充分フラッシング することが大切とされ，ASTM と ASME 合同委員 会 (1951) で,詳しくその方法を検討している。Clerk もフラッシングにテトラリンの使用などを紹介してい るが，わが国では高くつくので，とも洗いが専ら行わ れている現状である。

\section{III トランス油}

昭和27年度の電力供給量は 429 億 $\mathrm{kWh}$ に上り戦前 の 2 倍以上に達し, 新たに $275 \mathrm{kV}$ の送電線も建設せ られ，水力発電の開発が国策として力強く推進せられ ている現状に鑑みこれらに関係の深いトランス油を 取上げてみよう。この下ランス油はタービン油よりも さらに粘度が低く，長期間使用せられるも゙ので椧却と 絶緑を主目的としている。したがってスラッジ生成傾 向の大小を一番問題にしている。諸外国においてても， タービン油の場合のように酸化防止剤を使うことにつ いては赛用実験の最中で，まだ結論が出ていない。た だ, 今のところでは，添加版を使うことなく，天然に 
含紧れている成分觉活用して的こうという考え方が取 られている。少し詳細にトランス油を考元てみると， トランス油としては, たやすく蒸発しない範围で, 対 流し易いように粘度の低い油を選び，低温でも㠜固せ す $\left(-30^{\circ} \mathrm{C}\right.$ 以下 $)$, 引以や爆発しにくいもの望んで いる。長時間使用してむ, このような性質を失うこと なく持続けることが大切とされている。トランスの型 式によっても程度は違うが，使用中には温度も上り， 湿気も大り, 大気中の酸素も吸つて劣化してゆく。絶 縁耐力は湿気と固体微粒子などの混大で低下する。絶 縁油に油溶性の不純物が生成したために絶縁耐力が落 ちたのかにうかを見分けるには，G-4 グラス・フィ ルタで真空濾過後に耐電圧を測ってみると，もしも湿 気や溶解召スや固体微粒子の混在するために低下して いたものならばこれらが濾過操作中に除かれるため にすぐに $50 \mathrm{kV}$ 以上に上がる。さて酸化によつて酸性 物質ができると油中の水を乳化させ易くなり，スラッ ジができてくると油の循環や冷却を好げ温度が上る。 過酸化物ができてくると，トランス内の繊維物質に働 きかけて，キシ・セルローズをつくり，脆くする。し たがって油の酸化芷止めたり, 遅くできると, 油の保 守が大変に楽になる。そこで昭和 25 年 4 月に絶縁油部 会が発足し，現在までに43回の討議を重ね, 最近漸く その安定度試験法の原案がきまつた。昭和 29 年 4 月に 主査山田貞吉博士の出された報告をもとにして従来の 経過を顧み，いかにして独自の試験法が生まれてきた かを伝えたいと思う。

わが国で現在施行されている安定度試験法は試油 $40 \mathrm{cc}$ を径 $70 \mathrm{~mm}$, 高さ $110 \mathrm{~mm}$ のビーカに大れたも の 3 ケをつくり，これを予め $140^{\circ} \mathrm{C} に$ 加熱した恒温 油槽中に深さ約 $50 \mathrm{~mm}$ まで入れ, $20 \mathrm{hr}, 140 \pm 1^{\circ} \mathrm{C} に$ 保つたのち取出し, 室内に $20 \mathrm{hr}$ 放冷後濾過し, 濾紙 上に柝出物を認めるかどうかを調べたのち, 同一試料 について全酸価を測る。柝出物を認めないことと, 全 酸価 0.1 以下を規定している。この試験は緩く，ほと んぞの油が合格し，相互の優劣がはつきりしない。そ こで硫酸吸収量と安定度との間にはとんな関係がある かを検討した。一般に硫酸吸収量の多い:油は安定性が 瑟く，精製不充分なほぼ，その傾向がはつきりしてい る。しかし精製過度の油も硫酸吸収量は少ないに拘ら ず，安定性はすくない。したがつて硫酸吸收量のみで はその油の安定度の良否は断定できない。つぎに ASTM スラッジ試験法をみると, 試油 $25 \mathrm{cc}$ をとり, 径 $1 \mathrm{~mm}$ の銅舶 $30.5 \mathrm{~cm}$ をコイル状に巻いて加元, 油 浴学 $120 \pm 1^{\circ} \mathrm{C}$ に保ち, 毎時 $0.5 \pm 0.1 l$ の乾燥空気党
油面上に送る。72, 168, 336hr 連続酸化定行い，放冷 稀釈後,スラッジを濾過し, 乾燥科量する。50hr の試: 験でもその蓋がゆるいために $4 \%$ 以の蒸発量を示し ている。当然スラッジ量にも響くものと考元られ， $390 \mathrm{hr}$ 迄行つたが，スラッジは漸増の傾向を示してい た。つぎ英国の规格を検討している。本泑は試油 $100 \mathrm{~g}$ に, 厚さ $0.1 \mathrm{~mm}$, 縦 $51 \mathrm{~mm}$, 横 $32 \mathrm{~mm}$ の銅板 を入れ， $150 \pm 0.5^{\circ} \mathrm{C}$ に保ち，毎時 $2 l$ の空気を $45 \mathrm{hr}$ 吹込む。 $150^{\circ} \mathrm{C}$ は実用時に較へて高く、これでは絶縁， 油の劣化機構が変つてしまうのではないかと考光られ た。

ついで JIS 法の加熱時間を延長してみたが，蒸発量 が多く，冷却管蓋付きにし，銅線を添加するなど検討 した末に，ASTM 法とBSS 法のよい所を組み合せた 日立案が提案され，それを骨子とし各委員が充分梌討 した上,部会案が緾つた。その要領を簡単に述べると， 内径 $22 \mathrm{~mm}$, 長さ $300 \mathrm{~mm}$, の硝子管に $25 \mathrm{cc}$ の試油 をとり, 彺 $1 \mathrm{~mm}$, 長さ $800 \mathrm{~mm}$ の銅線をコイル状に して加元, $120^{\circ} \mathrm{C}$ の泊槽中に浸し，末端の水銀圧力訐 が $6 \mathrm{~mm}$ を保つように, 油面上に酸素を徐々に送り, 連続して $75 \mathrm{hr}$ 酸化を行う。終了後油槽外に取出し, 冷暗所に放冷後, 沈澱用テフサを加え, さらに約 $20 \mathrm{hr}$ 放冷し，濾紙にてスラッジを濾過し，洗深乾燥後秤量 する。スラッジ濾過後の濾液について酸価を測定す る。本法による安定度規格の JIS 原案としては, スラ ッジは $0.4 \%$ 以下，酸価は 0.6 以下にすることに定如 られた。

天然の原油中に含まれている酸化防止剤を適量残存 させることのみによつて，さらら苛酷な規格に合格さ せようとすると，自ら硫酸処理に限界があり，その原 油の組成い:かんによって製造上の難易の起るのは仕方 がない。タービン油の場合のように，極度に精製した のちに酸化防止刻を加えることが許されるならば，製 造が極めて確実に行える。電気機械メーカおよび使用 者側の方でも, 添加剤大りの絶縁油について実用実験 を重齐ているら，早晚これらの点も明らかにされる ことと思っている。

一方わが国においても，再生油が相当に繰返して使 われている。1952年 6 月，ニューヨークで行われた第 5 回絶縁油討論会の席上で, F. C. Doble の行つた絶: 縁油の再生についての意見を参考までに紹介したい。 Doble は絶縁油の品質低下灰次の三つにわけている。 まず湿気やゴミの大ることを contamination（活れ）” そ呼び, 圧濾機や遠心分離機で除去する工程を reconditioning (再調整) と呼び, 酸化を受けて酸やスラッ 
ジのできることを deterioration (劣化) と呼び，白土 処理や硫酸処理などで劣化物を除くことを rerefining （再精製）と称し，劣化や再精製工程中に最初含まれ ていた天然の酸化防止㧩の消耗することを depreciation（効力低下）之称し，合成酸化防止剈 (DBPC, ditertiarybutyl-p-cresol などをあげている) を加え て再生油の安定化を図ること老 inhibition（添加剤補 充）と呼んでいる。さきにタービン油の項でも述べた ように，油の劣化程度は水との界面張力を測ることに よって推定される。新油のときは 45〜 50dyne $/ \mathrm{cm}$ あ るが使用中に段々下り，20dyne $/ \mathrm{cm}$ 以下に落ちると

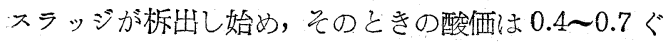
らいといわれている。

第1表に示すように，白土の使用量の増加するにし たがつて，界面張力は大となる。界面張力の高いほぼ， 添加剤の効果无優れているといわれている。しかし白 土の使用量の多いほぼ, 再生油の収率も下り, コス下 はかかるので, 経済的な見地から通常 30dyne 程度に 再生していると述心ている。わが国においても，再生 油の問題は今一歩研究を進める要があると思う。

第1 表 白土使用量と再生トランス油の界面張カ

$\begin{array}{llllllll}\text { 白土使用量 } & 0.00 & 0.10 & 0.17 & 0.33 & 0.66 & 1.10 & 1.85\end{array}$ $\begin{array}{cccccccc}\text { (換算)重量 } & 0 . & 1.36 & 2.32 & 4.50 & 9.0 & 15.0 & 25.2\end{array}$

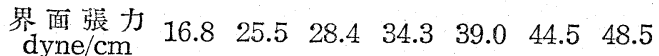

\section{H. D. エンジン油}

昨年も特ジーゼルエンジン泊に言及したが，近年特 に酸化安定性やベャリング歷蝕防止性および清浮分散 性能を有しているので，萠酷な使用條件下の高速ジー ゼル抢よびガりリン両機関に用いて適当な heavy duty 油を要求する声が高まつてきた。さらに米国で はこの上をゆく super duty油も現われてきたという 現状である。S. D. 油は，運転條件または燃料の不借 在も潤滑油の性能を高妃ことによつて解決しようと いう祖いである。さて目下のところ，このような $\mathrm{H}$. D. エンジン油の性能評価には，米英においても， L1 および L-4 テス下の次に实用走行試験を必要とし ている現状である。実用試験には多くの時間と費用が かかるので, 実験室的な物理化学的試験法で実用性能 を予知することができれぱまことに都合がよいわけ で, 潤滑油の性能向上も図り易くなる。われわれ油屋 はこれらの点に眊命な努力を重ねているが，特に片山 寛氏は一貫した研究を続け，26年 9 月に自動車潤滑油 の実用試験，29年 4 月には自動車エンジン油の性能評
価について講演し，研究問題の所在を明らかにした。 H.D. 油は清淨分散郕を含んで抢り，生成する煤や分 解生成物の微粒子に吸着して，これらを油中に懸濁さ せて分離沈積を防ぎ，ひいてはりング膠着を防止する といわれている。H. D. 油の清淨分散性は優れている が，これにも一定の限度があり，その能力以上に污損 物を抱えこむと，ついには分散状態にあつたものが一 時に油より沈積し，エンジン各部に堆積するようにな る。、油交換の時期を誤つてはならない。この清淨分散 性能の優位を実験室的に知るために，片山氏はセライ 下・クロマ下試験やカーボン沈降試験を紹介してい る。前者はセライト（白色珪藻土）を濾紙で約 $1 \mathrm{~cm}$ に区切り10数段と重ねたむので，試料を上段より注下 吸引すれば，清淨分散剂の胶果の強いものほど，カー ボンは油とともに展開して下ってゆく。また後者は試 油をトルエンなどで数百倍に稀勫し，遠心分離器にか けると，清淨分散性の不良なものは短時間で溶郕層と カーボンの層とにわかれるので，性能此較の一手段と 考えられる。同氏はさらに,シリカゲルを吸着版とし， 石油エーテル，ベンゼン，アルコールなどを展開脱着 剤として 粘度指数の 低いェンジン油の吸着分析を行 い, 多環芳香族化合物を取出し，ロウンン・エンジン を使って，これらが潜在ラッカ成分であることを明ら かにした。清淨分散剤を加えても，潜在ラッカ成分が ピストン上でラッカとなるのを防ぐ能力はないと結諭 している。われわれも Duo-Sol, Bari-Sol 法で仕上げ た特ジーゼルェンジン油の吸着分析它行つてみると， 単環宗たは複環芳香族化合物を残すのみで，多環芳香 族化合物は充分除去されていることを確認し，ロウy ン・エンジン・テ六下の結果ラッカ生成傾问のほとん どみられないことを認めた。

ところで清淨分散剤を添加したり，或は基油の精製 を極度に進めてゆくと，その債ではぞうしても酸化を 受け易くなり,ベャリングの腐蝕も激しくなつてくる。 これらを防ぐために酸化防止風やべャリング歷蝕防止 郕の添加が必要となる。われわれはこの語験のため に, Indiana Stirring Oxidation Test を推奨し，片 山氏は Sohio 酸化腐蝕試験を採用している。以上の ような物理化学的な試験で有效な添加刘の組合せがき まると、ロウソン H-2 エンジンなどにかけている。 周知のように，単筒，4サイクル・正リンエンジン $\left(258^{\prime \prime} \times 23 / 8^{\prime \prime}\right.$ ，纴縮比 5$)$ で，いろいろな運転試験法が ある。たとえば，安定性打よびべャリング腐蝕試験と

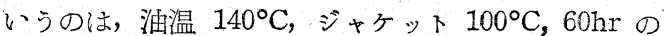
運転であり，分散性打よびッング膠着試験の方は，油 
温 $82^{\circ} \mathrm{C}$, ジャケット $177^{\circ} \mathrm{C}, 100 \mathrm{hr}$ 運転である。運 転後ぶャリングの重量減耗を笑測し，エンジン各部の 清浮度策評価し, 使用油の分析を併世行つて油の優劣 它判定する。

さてジェット・エンジンで世界の尖端をゆく英国に おいても，H. D. Type ェンジン油の規格 (B. S. 1905 : 1952) は第 2 表のような物理的性状を備元てい るほかに，米軍規格 MIL-O-2104に採用されている

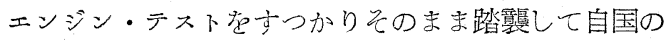
規格としている。いかにエンジン・テストが難しいも のであるかということと，長年にわたつて続けられた カタピラおよびゼネラル・モーターズ両社の試験法が
いかに卓越し，また各国の人々が率直に敬意を試軨法 に払つているかがわかる。ここに述へる C. R. C-L. 1-545 法は単筒 4 サィクル, ジーゼル, $\left(53 / 44^{\prime \prime} \times 8^{\prime \prime}\right)$ (燃料硫黄分 0.35 以上) Qカタピラ・テス下・エン ジンに，120hrごとに油を取換えながら，480hr 継続 運転を行い, リン分膠着, 摩耗および清浮性 (カーボ ン堆積）にに及济す潤滑油の影響を調べる。C. R. C-L. 4-949 法は 6 気筒 4 サイクル, ガソリン（オクタン価 $80 \mathrm{~mm}$ 以上）圧縮比 6.5 のシボレ・テス下・エンジン に，3,150r.p.m. で $36 \mathrm{hr}$ の運転を行い，酸滑油の酸 化抢よびベャリング腐蝕性觉調心゙。第 3 表に MILO-2104 と，本年改訂せられた MIL-L-2104A の物理

\begin{tabular}{|c|c|c|c|c|c|c|c|}
\hline & 5 & s & D. 油夫 & 爻に示され & 勿理的性状 & & \\
\hline & $10 \mathrm{~W}$ & $20 \mathrm{~W}$ & 20 & 30 & 40 & 50 & I. P. No. \\
\hline 引火点 ( ${ }^{\circ} \mathrm{C}$ 以上) & 182 & 182 & 182 & 199 & 204 & 204 & 36 \\
\hline 粘度 (cst $\left.210^{\circ} \mathrm{F}\right)$ & - & - & $5.75 \widetilde{9}$ & $9.65 \widetilde{12.98}$ & $\underset{16.82}{12.98 \sim}$ & $\underset{22.75}{16.82 \sim}$ & 71 \\
\hline (cst. $0^{\circ} \mathrm{F}$ ) & $\frac{1320 \sim}{2640}$ & ${ }_{10500}^{2640 \sim}$ & - & - & - & - & $\begin{array}{l}100^{\circ} \mathrm{F}, 210^{\circ} \mathrm{F} \\
\text { より外插 }\end{array}$ \\
\hline 粘度指数 （以上） & 85 & 85 & 55 & 55 & 55 & 75 & 73 \\
\hline 流動点 $\left({ }^{\circ} \mathrm{C}\right.$ 以下 $)$ & -23.3 & -23.3 & -20.6 & -17.8 & -9.4 & -9.4 & 15 \\
\hline
\end{tabular}

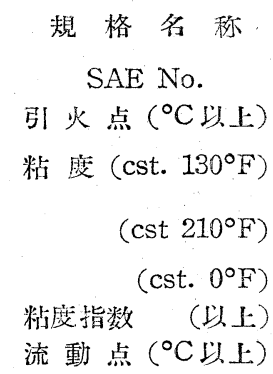

\section{第 3 表 米軍 H. D. 油規格の物理的性状 （* 改訂值）}

\begin{tabular}{|c|c|c|c|c|c|}
\hline \multicolumn{3}{|c|}{ MIL-O-2104 } & \multicolumn{3}{|c|}{ MIL-L-2104A } \\
\hline 10 & 30 & 50 & 10 & 30 & 50 \\
\hline 182 & 199 & 204 & 182 & 199 & 204 \\
\hline 18.1 $\widetilde{25.2}$ & ${ }^{39.8} \widetilde{\sim}$ & - & 一. & - & - \\
\hline- & - & $19.2 \sim \sim_{21.6}$ & $* 5.44 \sim 7.29$ & *9.65 12.98 & $\begin{array}{l}* 16.82 \sim \\
22.75\end{array}$ \\
\hline - & - & - & $* 2614$ & $* 43570$ & - \\
\hline 85 & 55 & - & - & - & 75 \\
\hline-23 & -17.8 & -9.4 & $*-28.9$ & -17.8 & -9.4 \\
\hline
\end{tabular}

的性状を参考未でに示しておく。前述の Superion Lubricants (Series-2oil) は過給器付カタピラ, 単筒 エンジンを使い，硫黄含量 $1 \%$ の燃料を使つた試験に 合格したものをいい，米軍ではこれに近い油をSupplement List 2 oil そ呼び，硫黄1\%で，L-1 テス下 に合格したもの学 Supplement 1 oil と呼んでいる由 である。清浄分散唷などの添加量が多いために高洒に なることは避けられない。以上のようなエンジン・テ ス下に合格した H. D. 油に使用されているえいう各 種の添加剤が多数売込まれてきている現状である。こ れらのうちから，自分たちの基油に適わしい添加剤の 組合せを決定してゆかねばならない。

\section{V 極王添加剤の効果と境界潤滑}

近年わが国では境界潤滑性能の検討に曾田教授考案の
4 球摩擦試験機が広く便われている。本試駼機に上る と，いろいろな境界潤滑状態の推移がよくわかる。摩 擦面間に二存在する油膜が比較的厚く, 吸着単分子層の ほかになお若干の非配列性の流動分子層官介在させて いると思方れる境界摩擦の第 1 領域と， その領域をす ざて，接触面中央の最高圧力部分で境界層が，市当種 の降伏を生じそこに抢ける摩擦が増大するために全 体の摩擦俰数が次第に増大す尚遷移領域と，それを経 過し，ついに摩擦面間の比較的厚い境界層が全面的に 降伏して，全面が抢えらく吸着単分子程度のうすい:油 膜のみで潤滑されるような第 2 領域に移り，第 2 領域 のうすい分子層すらもついに降伏して，瞬間的に焼き つき起す限界点に達する字で坊よくわかる。オンイ ン酸のように, 物理的吸着によつて, 潤滑性能を向上 
させるような真性油性向上剤は第 1 領域でのみ効果を 発揮しうるもので, 高圧高温下の第 2 領域では効果少 ないものであるといわれている。鉊不ケンもおもに， 第 1 領域で性能を発揮寸るものであるといわれてい う。いわ汤る極圧添加剤は主として，この第 2 領域で 真価を発揮するものである。そのためには必ず添加剈 が分解して，活性原子，たとえば $\mathrm{S}, \mathrm{Cl}, \mathrm{P}$ などが金 属面と反広することが前提條件である。極圧添加剤と はいらものの, 実は極圧に伴う摩擦面の極高温がこの、 効果学現わ寸主原因なのである。高温のために，分解 之同時に新しい化学反応がおこり，目的に応じた特殊 な金属被膜が生じ，その被膜の特性に応じて，いろい ろな形の耐圧性能を示す。硫化鉄の被膜は $300^{\circ} \mathrm{C}$ 前 後で 0.5 の摩擦釈数を示し, 化学的に安定で, その融 点む約 $1,180^{\circ} \mathrm{C}$ で鉄の融点 $1,535^{\circ} \mathrm{C}$ よりも低く, 1,500Å の厚さがあれば摩擦を低下させるのには充分 であるといわれている。塩化鉄の被膜は加水分解を受 けやすい点を除いては，大体同様な効果を示す。10.2 $\%$ \% を含む $\mathrm{Fe}$ そ $\mathrm{P}$ の共晶混合物の融点は $1,020^{\circ} \mathrm{C}$ に下る。このように摩擦面になじかができて，接触面 2圧力や温度を下げて摩耗を減らし, 耐圧性能をあげ るものといわれる。このような考元方て極圧に耐える ギヤ油などに要する添加剤が检討せられている。この 際に油膜の厚さ，従つて基油の粘度なども極めて大切 であり，金属接触面上に油の拡がつてゆく速度や浸み こんでゅくカの大小も重要な性質と考えられる。試験 鋼球面上に現われた摩耗痕の状況は顕微鏡などで充分 観察することも大切である。そこで,これら極圧潤滑に いたるまでの基本的な摩擦と潤滑についても, 筧田教 授のすぐれた解説を振り返つてみることにする。前述 の境界潤滑の第 1 領域に関係する油性について, “次の 結論が示されている。第一に，いわゆ方油性の直接の 原因はやはり分子の長さであつて，極性は第二義的で ある。配列は分子が長いためにおこる附帶的現象であ つて, 実際に摩擦の低下に有効なのは主として, 鎖式 分子の長さである。第二に，潤滑剤分子の配列の有無 が直接影響するのは, 主に静止摩擦に対してである。 軸受などにおいてて，始動および停止時に影響し，運 動摩擦では，しばしは配列層よりも高次の非配列分子 層が形成されて，それが配列の影響を覆うからであ る。第三に, 配列性の添加剤で, 室温や静止摩擦の成 績がよくても，しばしば実用に抢いて成績が上らない のは, 摩擦面温度が簡単に転移温度以上に昇り, 室温 における配列の有無が，全く無意味になるためであ る。従つて室温に打ける静止摩擦つ測定のみから,す
ぐれた油性向上剤を求めることは，特別の場合のほか は実用上あまり意味がない。以上のような潤滑境界層 は次の三つに分類されている。第一の単分子層は，金 属表面とむし万一体の固体被膜と方解す心き力学的に きわめて強勒な吸着層で，分子中の極性原子または極

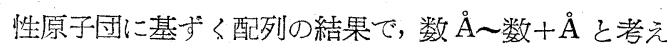
られる。第二の数分子層は第一の単分子層についで強 勒な著しい二次元的粘度增加の伴つた薄膜で，分子の 偏極に基ずいて多分子層の形成される“ディアヒシス” (diachysis) に上る配列で，数十〜数千 $\AA$ 之考元られ る。第三の薄膜は, 一種のゲル化層として, 静的には, かなりの厚さのものが形成されるが，力学的にはきわ めて弱く，わずかの機械的擾乱によつても，壞わされ て, 通常の粘性膜に転ずるようなコロイド的薄膜とみ

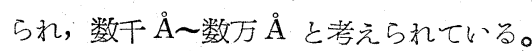

ハーディが方ラス, 鋼, 蒼鉛など各種の摩擦面に $n$ パラフィンを塗布して，それぞれ同種材料の摩擦片て 摩擦したときの静止摩擦係数をみると，使用した $n$ パラフィンの分子量いかんにかかわらず，常にガフス と鋼では 0.23 , 鋼 と蒼鉛では 0.09 だけの差が存在し， 境界摩擦保数の大小は結局, その乾燥摩擦倸数の大小 によって決定されることを明らかにした。さらに乾燥 摩擦は機械的転移温度をも決定する。したがつて，ま ず金属同志の乾燥摩擦の低いものを選び，それについ 七最も摩擦の低い，または機俄的転移温度の高い潤滑 剤を選心゙ばそそれがそのまま全組合せ中の最も摩擦の 低い，宗た機䑰的転移温度の高い組合せだということ となる。ここにいう機諓的転移温度とは，金属面に配 列していた方向性分子の単分子ないし，数分子層が熱 損乱の増大とともに，次第にその配列に緩るみができ て， ある温度近くになると急にその扡緩の度を增し て, 一種の固体の融解のような現象を呈し, 表面から 容易に離れやすくなる温度をいっている。潤滑用グす 一スを加熱してゆくと，よく似た順序で，グシース構 造の失われてゆくことが面白く感じられる。グラファ イトの潤滑作用が吸着分子層の作用によるものである ことが明らかにせられ，特に微量の水蒸気を吸着する と有効であることが Savage によつて示された。

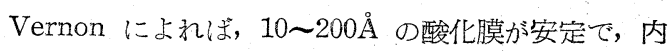
部金属の表面作用を強く防止しているという。 $\mathrm{Pb}$ や In で約 $0.5 \times 10^{-3} \mathrm{~mm}$ の厚さで, 摩擦俰数を著し く低下させるといわれている。軸受金の表面にこれ $5 \mathrm{~Pb}, \mathrm{In}, \mathrm{Sn}$ など低融点金属の薄膜をメッキすると, いずれも軟い金属であるため, 摩擦面に生する凝着部 分を剪断するのに必要な力は，これらの軟質金属の塗 
布によつて著しく低下する䈏である。すなわち摩擦面 の地肌の直接接触と，それに伴う凝着を妨げ，またそ の金属自体の剪断強さが低いということで，一種の潤 滑剤の作用在営むであ万うことが期待される。Cuに 約 $30 \%$ Pb 支混合したケルメットでは， $\mathrm{Pb}$ の融点 $327^{\circ} \mathrm{C}$ で急に摩擦が減少する。シリコンを使う潤滑 部に $\mathrm{Sn}$ 合金在推奨している理由もうなずける。摩擦 面の接触の問題は電動機の ブラシの接触の問題とし て提起されたものであるが，ジーメンスのホルムによ つて, 摩擦面にお汁る真実接触面積と見かけ上の接触

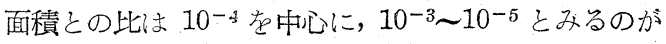
穏当であることが明らかにせられた。さらにとの真実 接触面積は荷重に正比例することが実験的に確めら れ，現在では乾燥摩擦の原因としては，2 面の㠜着部 を剪断するために生ずる抵抗であると考光る凝着説が 正しいと考えられるようになつてきている。徐々なが らも確実に解明されてゆく潤滑機構の研究成果を活用 して，未解決の分野，各種金属加工油剤の研究などに 進みたいものである。

\section{VIVッドウッド粘度と動粘度との関係}

従来わが国に抢ける石油製品の粘度の表示はレッド ウッド粘度計の秒数で示してきた。たとえは上述のタ

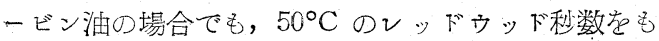
とにして90ヌービン油とか，180ヌービン油とか，呼 んでる。しかし世界的な傾向としても，技術的な便宜 を考慮してか，動粘度（センチ・ストーク）表示に移 ろうとしている。すでに当所の木下真清所員が、日本化 学会年会抢よび当燃料協会誌上にも発表し, 粘度分科 会でも述へているように，従来発表されている換算表 に検討を加光ている。これらの研究は地味な仕事では あるが，商取引」上には大切な要美をも含んでいるの で，簡単に触れてみたいと思う。だたま昭和石油社
内粘度計の補正を行うために動粘度既知の粘度標潐油 をもとにし，稻葉弥之助博士の換算表（ウッベローデ の数值を基淮) を使つてレッドゥッド sec. を求め, それぞれの粘度計の補正值を出したとこう，100 sec. 以下のところでは一定值に出なくて，最小值をもつた 曲線に従つて变動することがわかつた。粘度指数を概 算する際にも響いてくるし，商売上にもこれらの事柄 存はつきりさせることが必要なので，報告するととも に, 統計学的な扱い方を行つて次の実駼式を誘導し た。

$$
\begin{aligned}
& R=\frac{(4.044+0.000825 t) \nu}{\left(1-10^{\left.-0.068009 v^{0.95259}\right)}\right.} \\
& R \cdot \cdots \cdots \text { レッドヴッド（sec） } \\
& t \text {......温 度 } \quad\left({ }^{\circ} \mathrm{C}\right) \\
& { }_{\nu} \cdot \cdots \cdot \text {...動粘度 }
\end{aligned}
$$

これをもとにして換算表を算出し，その換算表を使 つて粘度㖕の補正を行つてみると比較的うまくゆくこ とがわかつた。

このことは岩波繁蔵博士の流体力学的な研究結果と 上く一致している。同様に行つたせイボル下粘度と動 粘度との関係についても同型の実験式が得られる。大 体研究も縓つたので, 近く木下所員より発表し御批判 克仰ぎたいと思っている。

\section{VII むす び}

以上この一年間に直面した潤滑油の諸閭題について 概説したが，使用面よりみた石油製品の適正品質の主 題に対しては，やや当を得ない感はあるが，日頃から 尊敬してい方諸権威の御意見をとのまま引用紹介する とともに，間題の在り場所について述へた次第であ る。終りに平素より潤滑油の研究に協丹していただい ている昭和石油社内関倸各位の御援助に深甚な謝意を 表市る。

\title{
Lubricating Oil
}

\author{
by Akira Wakana
}

(Shōwa Oil Cọ.,)

SYNOPSIS :- The author reviews the recent topics of lubricating oils, which are considered important and interesting. On turbine oil, the use of additive improves its performance excellently and good quality of turbine oil can be manufactured from Kuwait crude oil by using additive; on insulating oil, Japanese Industrial Standard test on oxidation stability and results of use of regenerating oil are mainly described; on motor oil, evaluation of Heavy Duty type oil is described. 
Morever, he discusses the effect of extreme pressure additives and its working mechanism, and explains the new calculation table of Redwood viscosity to kinematic viscosity.

U.D.C. 621.892 .5

\section{グリース潤滑剂総論}

一一昭和 29 年 10 月 20 日特別講演会講演—

丸善石泊株式会社中央研究所檀豐 三 郎

要旨: グリース潤滑剤について, その種類, 物理的和よび機能的性質, 構造, 添加剤, 防錆性能, 充填剤並びに物理的試験法の価值とその意義についての一般的な解說を行つた。な抌，軸受に礼け るグリースの潤滑作用についても諭及した。記述の重点は，とくにグリースの適正な選定と使用と に対する指針を与えるといらことに执かれている。

\section{I 緒 言}

グリース潤滑剤 (Lubricating Grease) の定義は， 一般に一種または数種の金属石簽と鉣油とから成るも ので潤滑に適当なものをいう。しかしながら最近にな つて広範囲にわたり提案された定義では，すなわち鉙 油に限らず広く液估潤渭剂に粘稠剤 (Thickener) t 分散してできた固体または半固体生成物であつて，な おこれに特別の性能を附与するためにその他の成分を 含屯場合がある。

グリースの製造歷史は相当に古く，現在のカップ・ グリースのような石灰石鹼と鉣油を原料とする石灰石 睑基グリースは既に1845年頃から製造されたといわれ ているが，その後ヘルッやストリベック両氏が球軸受 の潤滑剤としてがリースを注目するようになつてか ら, その性能に改良が加えられ, さらに最近10年間の 機㑘の発展はこの樣相を一変し, 独特の潤滑およびら゙ リースの適用がっ・とりわけ工業の進展に必要となつて きた。

グリース潤滑剤の使用者, むしくは消費者の興味は, グリースの種類とかその外形によつてどのようにグリ ースを認識したらよいか，また撰定したグリースから ぞのような性能が期待されるかという点である。この ためには，まず各種グリースについて基本的な知識を もつことが必要である。

グリースは今日その種類とか形状からみて多敇多様 なものがある。その製造処方からみて極めて単一なる のから非常に複雑なものまであつて, 高度の技術を加 えたものもある。適当な稠度または適正な種類のグリ
一スが撰定され，正しく適用される場合には, グリー スの性能が充分に登掩される。ここで，われわれはグ リースの用途または製品についての説明を一般化する ために，各種用途に使われるグリースの種類を次の四 つの基本分類に分けて考えることとする。

(1) 運転温度 $-15^{\circ} \mathrm{C}$ から約 $70^{\circ} \mathrm{C}$ までの範团に 適用される耐水性型グリース(Water-resistant type)。 この分類に属すものに，一般にカルシャム和よびアル ミニゥム石䍅基グリースがある。

(2) 運転温度 $0^{\circ} \mathrm{C}$ 以上, $140 \sim 200^{\circ} \mathrm{C}$ の䉇囲に適 用される水溶性型グリース(Water soluble type)。こ の分類に属するものはンーが石鹼基グリースである。

(3) 万能性ク゚リース (Multi-purpose greases)。 即ち耐水性で低温抢よび高温に適用できるもの。

(4) 合成グリース (Synthetic greases) 天然鉱 油に代り合成油を使用して製造したものである。

\section{II 耐水性型グリース}

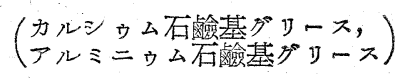

（1）カルシゥム石瞼基グリースこのク゚リースは 加熱媒体として蒸気開放式または密閉釜で鹼化して製 造する。石羷基の組成は牛脂または鯨脂の脂肪酸を石 灰と水で酸化する。石睮ができてから適当な鉣油を徐

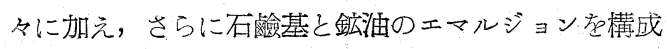
するために必要量の水を加えてでき上つたグシースの 稠度や硬さを保持する。例えば軟質グリースでは，通 常鉣油分約 $90 \%$ ，水分痕跡加 $51 \%$ ，石䌞分約 $10 \%$ ， その稠度は 310〜340である。また硬質グリースでは， 